\title{
USING POLYCARBOBETAINES FOR CU RECOVERY FROM CATHOLYTES GENERATED BY ELECTRODIALYTIC TREATMENT OF SEWAGE SLUDGE ASH
}

\author{
GUNVOR M. KIRKELUND ${ }^{1}$ \& JULIA MOUTON ${ }^{2,3}$ \\ ${ }^{1}$ DTU Civil Engineering, Technical University of Denmark, Denmark \\ ${ }^{2}$ EPF-Graduate School of Engineering, France \\ ${ }^{3}$ Sorbonne Universités, France
}

\begin{abstract}
Electrodialytic remediation is a process that uses a low current density to remove heavy metals from different waste matrixes such as sewage sludge ash (SSA). The SSA is suspended in water and separated from the anolyte and catholyte compartments by ion exchange membranes. The heavy metal cations are separated from the ash and electromigrate into the catholyte, where they can electrodeposit on the cathode. Despite this electrodeposition, the catholyte contains heavy metals after the remediation process. Newly developed water-soluble polycarbobetaines (PCBets) have shown potential for selective removal of metal ions and especially $\mathrm{Cu}$ in synthetic solutions. In this study, it was investigated for the first time if the PCBets can remove $\mathrm{Cu}$ from the catholytes generated by electrodialytic remediation. Four electrodialytic separation experiments were made, treating SSA in slurries at liquid to solid ratios 3.5:21. The Cu removal from the SSA was between 6-30\%, resulting in catholyte concentrations between $0.18-4.34 \mathrm{mg} \mathrm{Cu} / \mathrm{l}$. The $\mathrm{Cu}$ selective PCBet, PCEAC was added to the four different catholytes for $\mathrm{Cu}$ extraction after a $\mathrm{pH}$ adjustment to around five of the catholytes. The removal of $\mathrm{Cu}$ was almost negligible by the PCEAC, regardless of the initial $\mathrm{Cu}$ concentration. Thus, the samples were spiked with $\mathrm{Cu}$ to concentrations between $77-319 \mathrm{mg} / \mathrm{l}$ and then the removal of $\mathrm{Cu}$ was tested by the addition of PCEAC or PCEAMC from the catholyte solution, resulting in $\mathrm{Cu}$ removals up to $70 \%$ and $40 \%$ respectively. However, a significant co-adsorption of $\mathrm{Al}, \mathrm{Ca}$ and $\mathrm{Zn}$ was also seen. Based on the results, there is a potential in combining the use of PCBets to electrodialytic treatment, however the metal concentration in the catholyte should be increased and the PCBets should be further developed to avoid co-adsorption.
\end{abstract}

Keywords: electrokinetic remediation, polymer, heavy metal, remediation, precipitation, valorisation, wastewater.

\section{INTRODUCTION}

Electrokinetic remediation is a method for removing mainly heavy metals from contaminated materials by applying an electric field. At the electrodes, protons and hydroxyl are produced due to water splitting and are transported towards the electrode of opposite charge. The acidic front caused by the protons mobilises the heavy metals, which can be removed by electromigration. The alkaline front from the cathode is unwanted, as heavy metals will precipitate at high $\mathrm{pH}$. In electrodialytic remediation, ion exchange membranes are used to hinder this transport, however the material is still acidified due to water splitting at the anion exchange membrane. Electrodialytic remediation has been applied to many different materials such as soils, sediments and different ashes [1]. Sewage sludge ash (SSA) is rich in phosphorous, which is becoming a scarce element. Therefore in Denmark, the Danish government has set as target that $80 \%$ of phosphorous should be reused from wastewater sludge and ash by 2020. Electrodialytic remediation of SSA has shown to be an efficient method to separate phosphorous, mineral ash and heavy metals into separate fractions, see Fig. 1. 


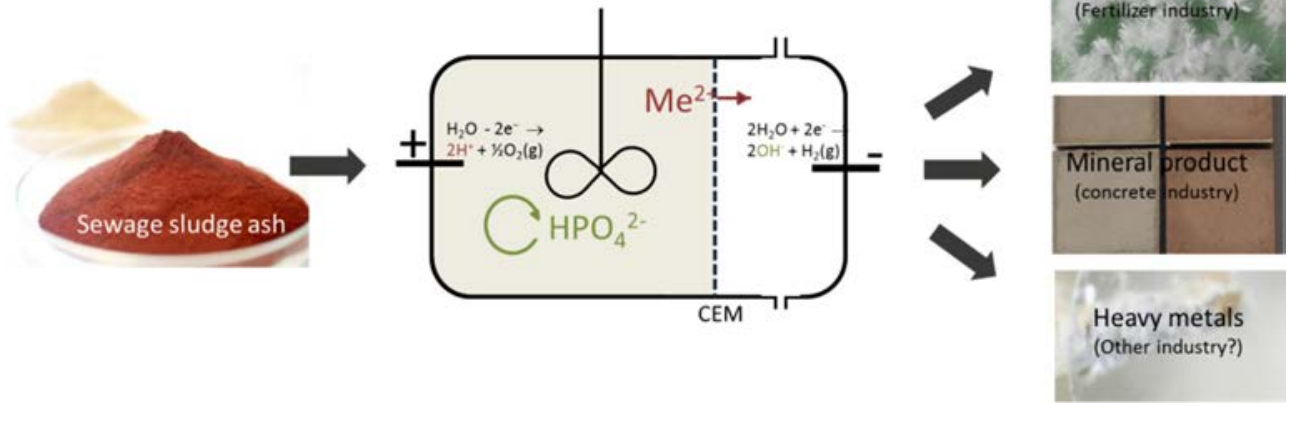

Figure 1: Electrodialytic separation of sewage sludge ash into resources: phosphorous for production of fertilizer, a mineral product for use as filler in concrete and heavy metals which may find use in other industry.

Up to $90 \%$ phosphorous has been extracted from Fe rich SSA, and a phosphorous salt with a low content of impurities can be produced [2], while the remaining mineral ash can substitute $20 \%$ cement in mortars, without significant reduction in mortar properties [3]. This means that this method has an economic potential for large scale use, as the disposal fee for SSA can be avoided and instead the resources in the SSA can be valorised. In the electrodialytic cell, the heavy metal cations are separated from the ash and electromigrate into the catholyte, where they can electrodeposite on the cathode. Despite this electrodeposition, the catholyte contains heavy metals after the remediation process and a way to treat the electrolytes is necessary for full scale implementation.

Various techniques for removal of metals from wastewaters have been developed [4], where precipitation is an economically attractive method. However, precipitation has the drawback when treating wastewaters with several metals that a co-precipitation of metals will happen with a following limited valorization of the metals. Therefore, adsorbents with a high selectivity for specific metals in a multielement solution and with high adsorption capacities could have a great potential. One group of adsorbents are synthetic polybetains, where novel water-soluble polycarbobetaines (PCBets) have shown potential for selective removal of metal ions from solutions. The PCBets have especially shown good results of up to $100 \%$ removal of $\mathrm{Cu}$ in synthetic solutions, however PCBets have still not been tested with real contaminated samples [5], [6].

The aim of this study was to investigate, for the first time, if PCBets could remove $\mathrm{Cu}$ selectively from the catholytes generated by electrodialytic remediation of SSA and add to the valorization of resources in SSA. Any simultaneous removal of $\mathrm{Al}, \mathrm{Ca}, \mathrm{P}$ and $\mathrm{Zn}$ from the catholytes by the PCBets are also reported.

\section{MATERIALS AND METHODS}

The experimental sewage sludge ash was from the Danish wastewater treatment plant Mølleåværket, where the SSA is incinerated in a fluidized bed incineration process. At the wastewater treatment plant, phosphorous is removed from the wastewater by precipitation with Al. The SSA was kept at room temperature in sealed plastic containers until the experimental work was made. 


\subsection{Analytical procedures}

Heavy metal and phosphorous concentrations in the sewage sludge ash were measured by ICP-OES (induced couples plasma-optical emission spectrometry) after pre-treatment by Danish Standard DS259, where $1 \mathrm{~g}$ of ash and $20 \mathrm{ml} 7.3 \mathrm{M} \mathrm{HNO}_{3}$ were heated at $200 \mathrm{kPa}$ $\left(120^{\circ} \mathrm{C}\right)$ for $30 \mathrm{~min}$. The liquid was thereafter separated by vacuum filtration through a $45 \mu \mathrm{m}$ filter and diluted to $100 \mathrm{ml}$. The digestions were made in triplicates.

\subsection{Electrodialytic remediation experiments}

The electrodialytic remediation experiments were made in a three-compartment cell, as shown in Fig. 2. The SSA was suspended in water and separated from the anolyte and catholyte compartments by ion exchange membranes. Four electrodialytic experiments were made, at four different liquid to solid (L/S) ratios; 3.5, 7, 14 and 21. During all experiments a constant current of $50 \mathrm{~mA}$ was applied for one week. The cell was made of Plexiglas, compartment II was $10 \mathrm{~cm}$ long and had an internal diameter of $8 \mathrm{~cm}$. The electrolyte compartments (I and III) were separated by either cation (CAT) or an anion (AN) exchange membranes, to concentrate the removed metals in compartments I and III. The ion exchange membranes were from Ionics (anion exchange membrane 204 SZRA B02249C and cation exchange membrane CR67 HUY N12116B). The electrolytes were $0.01 \mathrm{M} \mathrm{NaNO}_{3}$ adjusted to $\mathrm{pH}<2$ with $1: 1 \mathrm{HNO}_{3}$ and $500 \mathrm{~mL}$ electrolyte circulated in compartments I and III. "Pan World" pumps with a flow rate of $2.6 \mathrm{~L} \mathrm{~min}^{-1}$ were used to circulate the electrolytes. The electrolytes were optimized for electrodialytic remediation, not for PCBet testing. Platinum coated titanium electrodes from Permascand were used as working electrodes and a power supply (Hewlett Packard E3612A) was used to maintain a constant DC current. pH and electrical conductivity were measured in the sewage sludge ash suspension daily.

After the electrodialytic experiments, the sewage sludge ash suspension was filtered through a $45 \mu \mathrm{m}$ filter and the heavy metal and phosphorous content was measured in the filtered liquid and the ash solids. The stirrer, membranes and electrodes were rinsed in acid, to measure the amount of heavy metals adsorbed onto these. The heavy metal content was also measured in the electrolytes (anolyte and catholyte). The full volume of the catholytes was kept for PCBets experiments and named C-L/S X $(X=3.5,7,14$ or 21). All the samples were measured by ICP-OES.

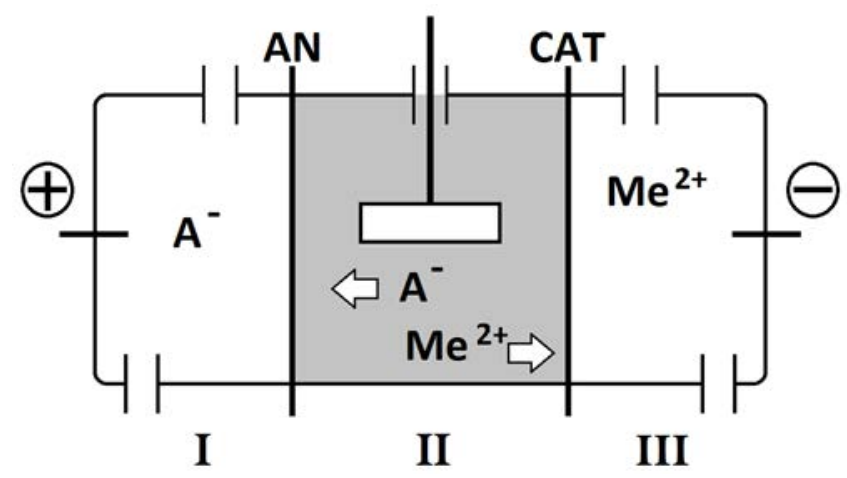

Figure 2: Three compartment electrodialytic cell. AN - anion exchange membrane, CAT - cation exchange membrane, A - anion, Me - metal ion, I - anolyte compartment, II - suspension compartment, III - catholyte compartment. 


\subsection{PCBets experiments}

Two PCBets were used for the $\mathrm{Cu}$ removal from the catholytes: polycarboxyethyl-3aminocrotonate (PCEAC) and polycarboxyethyl-3-aminomethylcrotonate (PCEAMC). The PCBets were synthesised and characterized (results not shown) according to the procedure described by Mouton et al. [5]. Methacrylic acid was used in the synthesis of PCEAMC instead of acrylic acid as in the synthesis of PCEAC. The chemical structures of each are shown in Fig. 3.

\subsubsection{With catholytes from electrodialytic remediation experiments}

The full protocol is given in Fig. 3 and was operated in triplicate. The $\mathrm{pH}$ of catholytes was first adjusted from $\mathrm{pH} 2$ to $\mathrm{pH} 5$ with $\mathrm{NaOH}$, due to the $\mathrm{pH}$ sensitivity of PBCets [5]. Some elements were visibly precipitated and the solution was then filtered at $0.45 \mu \mathrm{m}$ and the $\mathrm{pH}$ adjusted catholyte sample was named $\mathrm{C}-\mathrm{L} / \mathrm{S} \mathrm{X}_{\mathrm{pH} 5}$. The filtrate was dried at $105^{\circ} \mathrm{C}$ and kept for analysis (if needed). The solution was sampled for initial metal ion concentration. Then $260 \mu \mathrm{L}$ of PCEAC solution at $1 \mathrm{~g} / \mathrm{L}$ in distilled water was added for a final concentration of $10.4 \mathrm{mg} / \mathrm{L}$. The solution was left under stirring for 30 minutes and then filtered at $0.45 \mu \mathrm{m}$, where the liquid fraction (sample named C-L/S $\mathrm{X}_{\mathrm{pH} 5-\mathrm{PCBets}}$ ) was collected and kept for ICPOES analysis. The solid fraction (filtrate) was dried at $105^{\circ} \mathrm{C}$ and kept for mineralization and ICP-OES analysis if needed.

2.3.2 With spiked electrodialytic remediation experiment catholytes

A mix of all the four catholytes were also spiked with higher concentrations of $\mathrm{Cu}$, to further investigate the efficiency of the PCBets in real wastewater samples. The samples were spiked with $\mathrm{Cu}$ to concentrations between $77-319 \mathrm{mg} / \mathrm{l}$ and both PCEAC and PCEMAC were tested to precipitate $\mathrm{Cu}$. A bulk catholyte sample was used for these experiments (named $\mathrm{C}-\mathrm{M}$ ) consisting of a mix of all the catholytes from the electrodialytic experiments.

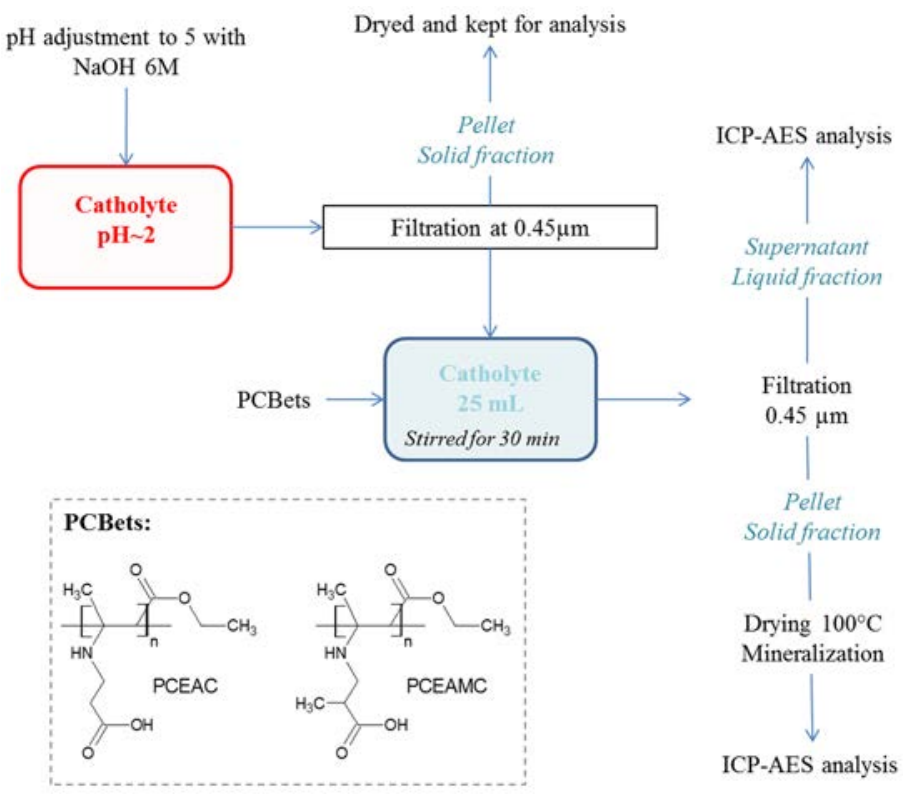

Figure 3: Experimental protocol for the PCBet tests with catholytes. 


\section{RESULTS AND DISCUSSION}

\subsection{Electrodialytic experiments}

The element removal in the electrodialytic experiments is seen in Fig. 4. Overall, the highest removal was seen in experiment $\mathrm{L} / \mathrm{S} 21$, which had the lowest $\mathrm{L} / \mathrm{S}$ ratio. This removal is highly linked to the $\mathrm{pH}$ of the SSA suspension, which was decreasing fastest to an acidic level in this experiment (Fig. 5), as both metal and P release from SSA is highly pH dependent [7]. Metals are mainly removed towards the cathode as cations in the electrodialytic cell, where they also can undergo electrodeposition by the cathode. In electrodeposition the heavy metal cation can be removed and recovered at the cathode by cathodic reduction of the cation to the metallic state. The efficiency of electrodeposition of metal cations is dependent on several factors such as electrode material, current density, electrode surface area and the electrolyte solution matrix [8]. Electrodeposition occur in the catholytes of the electrodialytic cell (can be visually seen as deposits on the electrode) and the percentage distribution of $\mathrm{Cu}$ at the cathode versus found in the catholyte is shown in Fig. 6. The electrodialytic cell is not designed for electrodeposition at the cathode, but for removal and separation of heavy metals and elements from the waste material. However, deposition of $\mathrm{Cu}$ often occur in electrodialytic remediation experiments, since the standard potential of $\mathrm{Cu}$ reduction is positive $\left(\mathrm{E}_{\mathrm{e}}{ }^{\theta}=0.34 \mathrm{~V}\right)$, but is however competing with $\mathrm{Fe}\left(\mathrm{E}_{\mathrm{e}}{ }^{\Theta}=0.77 \mathrm{~V}\right)$ if present. All these factors are influencing the electrodeposition and is causing the difference seen in Fig. 6. However, these factors will not be specified further.

The element concentrations in the catholytes after the electrodialytic remediation experiments are shown in Table 1. The initial metal content in SSA [7] is low compared to the concentrations found in MSWI fly ash [9] or for the Cd concentrations in bioashes [10]. Typical catholyte concentrations after electrodialytic remediation experiments for these ashes are included in Table 1 for comparison. The $\mathrm{Cr}, \mathrm{Pb}$ and $\mathrm{Zn}$ concentration level in the catholytes was lower for than in catholytes from experiments with MSWI fly ash, which are the main metals in MSWI fly ash. However for $\mathrm{Ba}$ and $\mathrm{Cu}$, the catholyte concentrations were at a similar level. When comparing to bioash, it was seen that the Cd concentrations in the catholyte from the electrodialytic remediation experiments are negligible in the present study.

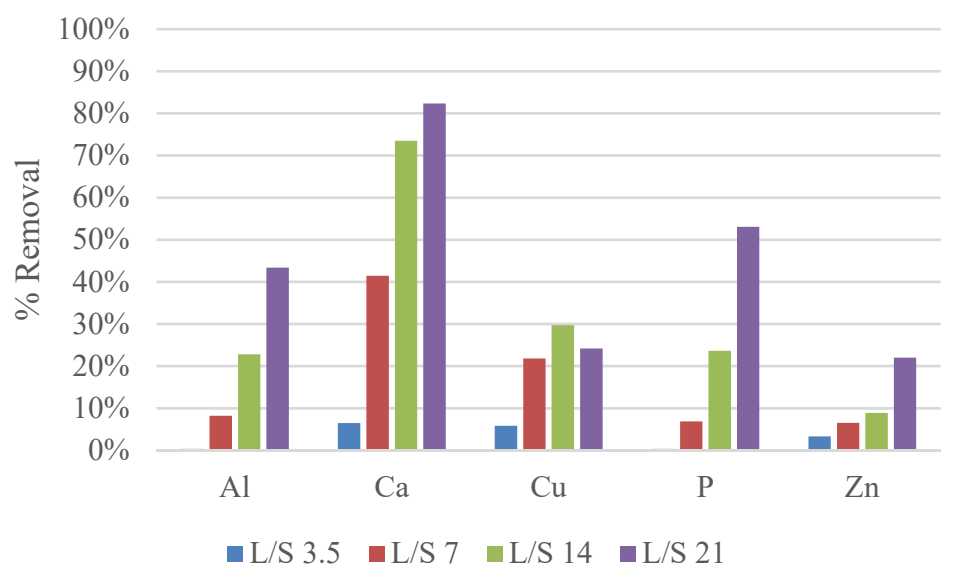

Figure 4: Element removal in the electrodialytic experiments. 


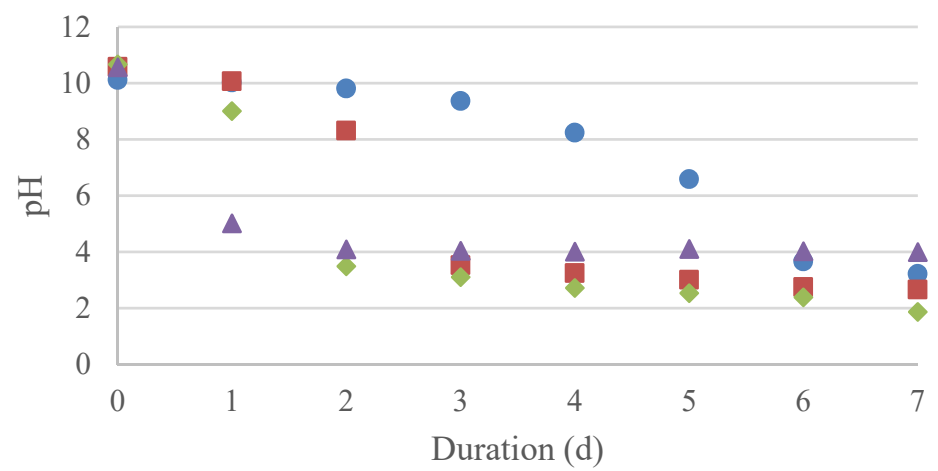

$\bullet \mathrm{L} / \mathrm{S} 3.5 \square \mathrm{L} / \mathrm{S} 7 \bullet \mathrm{L} / \mathrm{S} 14 \Delta \mathrm{L} / \mathrm{S} 21$

Figure 5: $\mathrm{pH}$ in the suspension compartment during the electrodialytic experiments.

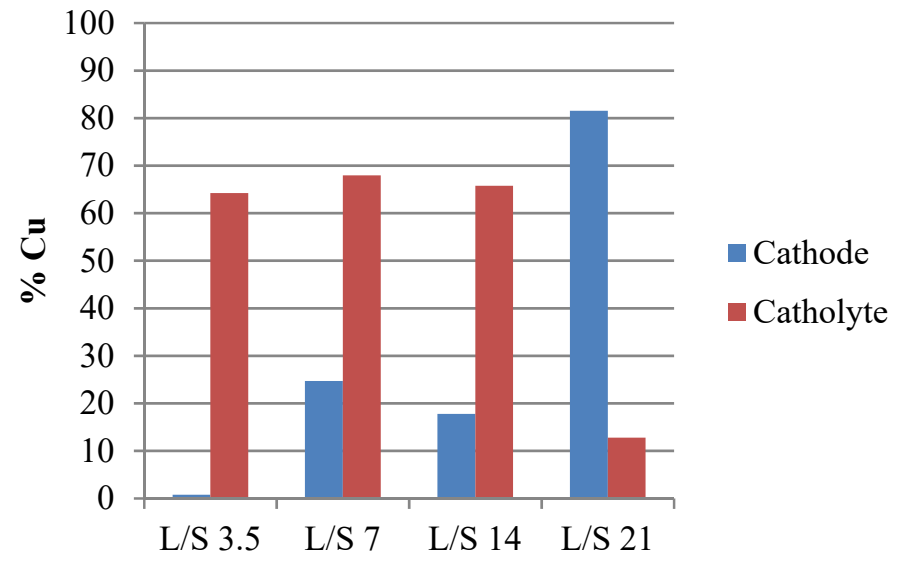

Figure 6: Percentage of removed $\mathrm{Cu}$ found at the cathode versus the catholyte in the electrodialytic experiments.

Table 1: Concentrations $(\mathrm{mg} / \mathrm{L})$ in the catholytes after the electrodialytic remediation experiments of SSA and from other ashes.

\begin{tabular}{|l|c|c|c|c|c|c|c|c|c|c|}
\hline & $\mathrm{Al}$ & $\mathrm{Ba}$ & $\mathrm{Ca}$ & $\mathrm{Cd}$ & $\mathrm{Cr}$ & $\mathrm{Cu}$ & $\mathrm{Fe}$ & $\mathrm{P}$ & $\mathrm{Pb}$ & $\mathrm{Zn}$ \\
\hline C-L/S 3.5 & 20.9 & 0.3 & 610 & 0.01 & 0.02 & 2.3 & 1.6 & 2.0 & 0.04 & 4.0 \\
\hline C-L/S 7 & 7.3 & 0.02 & 41.2 & 0.02 & 0.009 & 0.29 & 0.05 & 50.8 & 0.31 & 0.31 \\
\hline C-L/S 14 & 706 & 1.42 & 1858 & 0.02 & 0.08 & 3.3 & 7.7 & 375 & 0.12 & 4.4 \\
\hline C-L/S 21 & 68.6 & 3.1 & 304 & 0.01 & 0.03 & 0.18 & 3.7 & 9.9 & 0.24 & 3.1 \\
\hline C-M & 12.5 & 0.0 & 729 & 0.01 & 0.01 & 1.6 & 0.2 & 3.6 & 0.11 & 3.7 \\
\hline MSWI FA [9] & - & $1.2-1.8$ & - & - & $0.1-1.5$ & $0.4-1.2$ & - & - & $3-68$ & $14.5-23$ \\
\hline Bioash [10] & & & & $0.5-4$ & & & & & & \\
\hline
\end{tabular}




\subsection{PCBets experiments with real catholytes}

The results of the experiments with PCBets additions to the catholytes are seen in Table 2; the initial concentration in the catholyte, after $\mathrm{pH}$ adjustment to $\mathrm{pH} 5$ and after the addition of PCBets and filtration step for $\mathrm{Al}, \mathrm{Ca}, \mathrm{Cu}, \mathrm{P}$ and $\mathrm{Zn}$. In the $\mathrm{pH}$ adjustment step, $\mathrm{Al}$ and $\mathrm{P}$ were removed, which could also be seen as a white precipitate, probably some Al-Phydroxide. The $\mathrm{Ca}$ concentrations were not influenced by the $\mathrm{pH}$ adjustments; however, $\mathrm{Cu}$ was also to some extent removed from the solution. There was no difference in the element concentrations after the step with PCBets addition compared to the $\mathrm{pH}$ adjusted catholytes. $\mathrm{Cu}$ will make complexes with the PCBets but are water soluble below a concentration below $63 \mathrm{mg} / \mathrm{L}$ and the complexation thus cannot be seen in the results in Table 2.

\subsection{PCBets experiments with spiked catholytes}

These experiments were made to test if the catholyte solution matrix was compatible with the PCBets. The results with the $\mathrm{Cu}$ spiked catholyte are shown in Table 3, where both PCEAC and PCEAMC were tested. At these higher $\mathrm{Cu}$ concentrations, the removal by the PCBets is clearly seen. At the same time a quite significant Al removal was also observed. This is not due to complexation with the PCBets, which should then also have been observed

Table 2: Concentrations $(\mathrm{mg} / \mathrm{L})$ in raw catholytes, after $\mathrm{pH}$ adjustment and after adding PCEAC.

\begin{tabular}{|c|c|c|c|c|c|}
\hline & $\mathrm{Al}$ & $\mathrm{Ca}$ & $\mathrm{Cu}$ & $\mathrm{P}$ & $\mathrm{Zn}$ \\
\hline C-L/S 3.5 & 20.9 & 610 & 2.3 & 2.01 & 3.98 \\
\hline C-L/S 3.5 & 10.8 & 597 & 1.94 & 0.04 & 3.43 \\
\hline C-L/S 3.5 pH5-PCBets & 10.8 & 597 & 1.99 & 0.13 & 3.73 \\
\hline C-L/S 7 & 7.3 & 41.2 & 0.29 & 50.8 & 0.31 \\
\hline $\mathrm{C}-\mathrm{L} / \mathrm{S} 7_{\mathrm{pH} 5}$ & 1.6 & 41.2 & 0.1 & 8.04 & 0.27 \\
\hline C-L/S 7 pH5-PCBets & 1.9 & 41.1 & 0.18 & 8.83 & 0.29 \\
\hline C-L/S 14 & 706 & 1857 & 3.34 & 375 & 4.38 \\
\hline C-L/S $14_{\mathrm{pH} 5}$ & 25.5 & 1858 & 2.42 & 13.1 & 4.62 \\
\hline C-L/S 14 1 pH5-PCBets & 18.1 & 1840 & 2.49 & 7.4 & 4.77 \\
\hline C-L/S 21 & 68.6 & 304 & 0.18 & 9.95 & 3.13 \\
\hline C-L/S 21 $1_{\mathrm{pH} 5}$ & 5.5 & 316 & 0.08 & 0.0 & 2.39 \\
\hline C-L/S $21_{\mathrm{pH} 5 \text {-PCBets }}$ & 5.3 & 318 & 0.07 & 0.0 & 2.42 \\
\hline
\end{tabular}

Table 3: Concentrations (mg/L) in spiked catholytes after adding PCBets.

\begin{tabular}{|c|c|c|c|c|c|c|c|c|}
\hline \multirow{2}{*}{$\begin{array}{c}\text { Spiked } \\
\text { Cu conc. }\end{array}$} & \multicolumn{4}{|c|}{ PCEAC } & \multicolumn{4}{c|}{ PCEAMC } \\
\hline & $\mathrm{Al}$ & $\mathrm{Ca}$ & $\mathrm{Cu}$ & $\mathrm{Zn}$ & $\mathrm{Al}$ & $\mathrm{Ca}$ & $\mathrm{Cu}$ & $\mathrm{Zn}$ \\
\hline 0 & 12.5 & 729 & 1.6 & 3.7 & 12.5 & 729 & 1.6 & 3.7 \\
\hline 319 & 3.7 & 279 & 169 & 1.8 & 3.3 & 286 & 191 & 1.7 \\
\hline 255 & 4.2 & 345 & 122 & 2.0 & 3.9 & 363 & 145 & 2.0 \\
\hline 205 & 4.6 & 401 & 87 & 2.3 & 4.6 & 434 & 115 & 2.4 \\
\hline 153 & 4.9 & 474 & 59 & 2.8 & 5.3 & 505 & 88 & 2.8 \\
\hline 128 & 4.9 & 485 & 43 & 2.9 & 5.7 & 520 & 74 & 2.8 \\
\hline 102 & 4.8 & 509 & 31 & 3.1 & 6.7 & 544 & 64 & 3.0 \\
\hline 77 & 5.1 & 582 & 22 & 3.3 & 7.9 & 599 & 53 & 3.3 \\
\hline
\end{tabular}


in the unspiked samples. It is probably rather caused by an adsorption of $\mathrm{Al}$ to the $\mathrm{Cu}$-PCBets complexes. The same observation is made for $\mathrm{Ca}$ and $\mathrm{Zn}$.

The removal in percentage of $\mathrm{Al}, \mathrm{Ca}, \mathrm{Cu}$ and $\mathrm{Al}$ are shown in Fig. 7. It is clear that the PCEAC provided the highest removal of $\mathrm{Cu}$ from the spiked catholytes, with the highest removal up to $70 \%$ at the lowest spiked $\mathrm{Cu}$ concentrations. Contrarily for the PCEAMC, the highest removal was seen at the highest spiked $\mathrm{Cu}$ concentration, however no more than $40 \%$ removal was observed.

The simultaneous removal of $\mathrm{Al}, \mathrm{Ca}$, and $\mathrm{Zn}$ is also observed from Fig. 7 for both PCBets which differs from previous results obtained for PCEAC [5]. The methodology used in this previous article [5] was considering other metal ion adsorption favouring copper desorption.

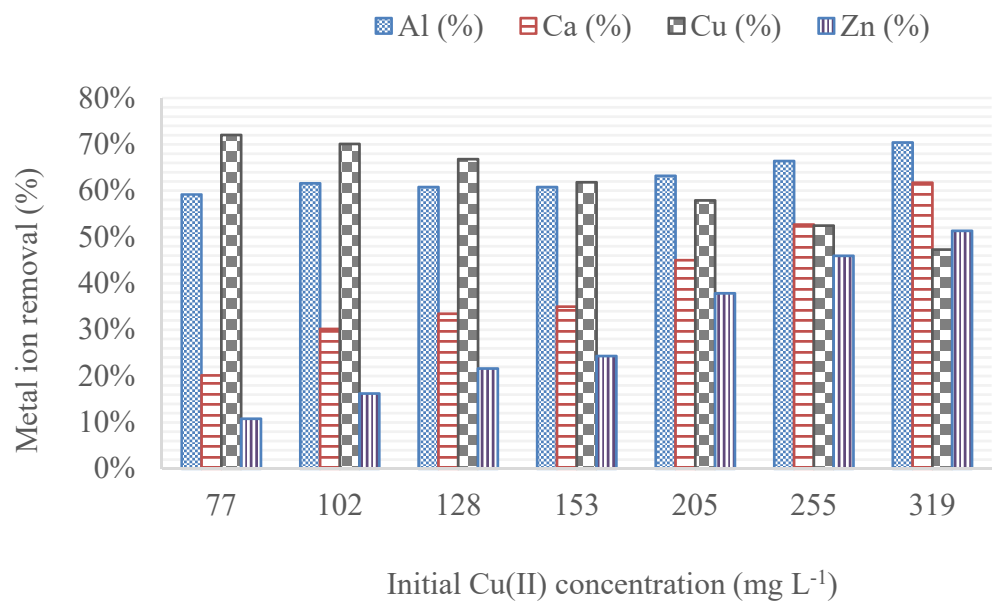

(a)

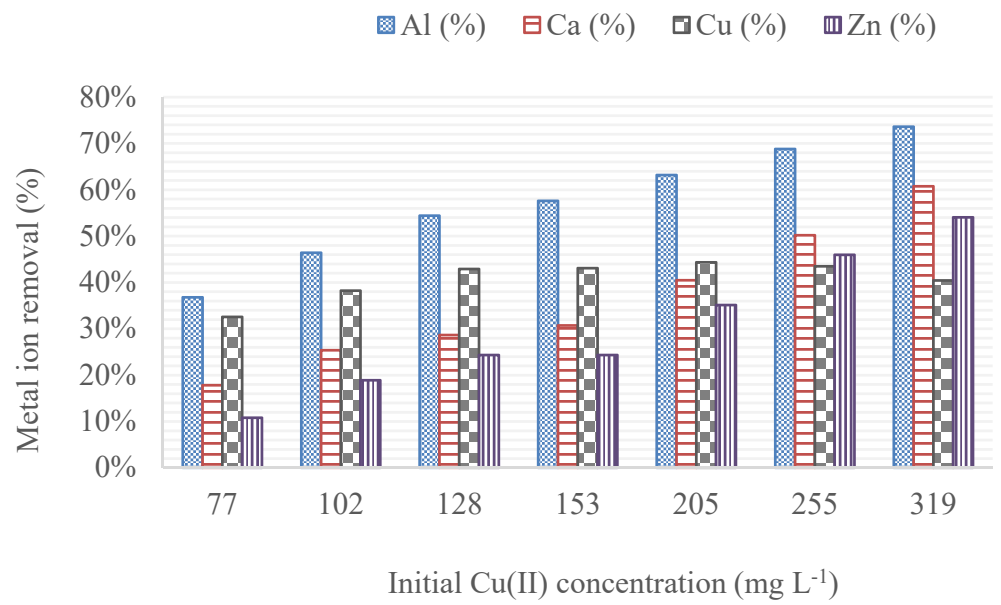

(b)

Figure 7: Removal of $\mathrm{Al}, \mathrm{Ca}, \mathrm{Cu}$ and $\mathrm{Zn}$ from spiked catholytes: (a) with PCEAC; and (b) with PCEAMC. 


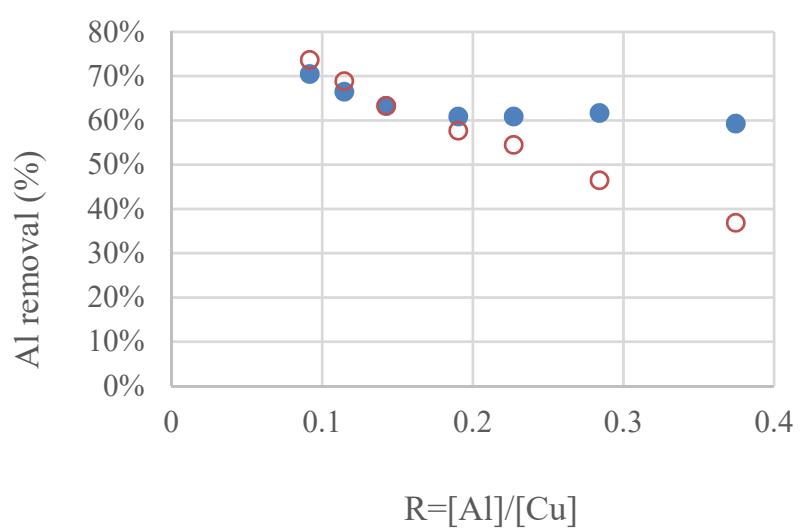

(a)

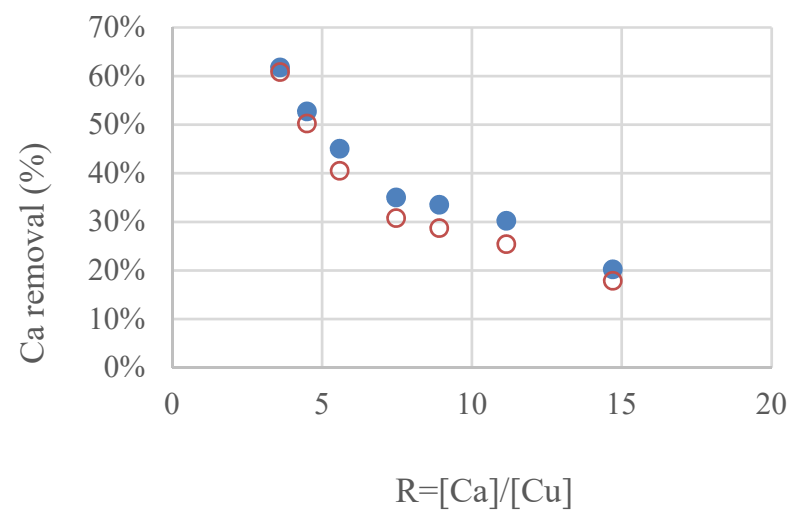

(b)

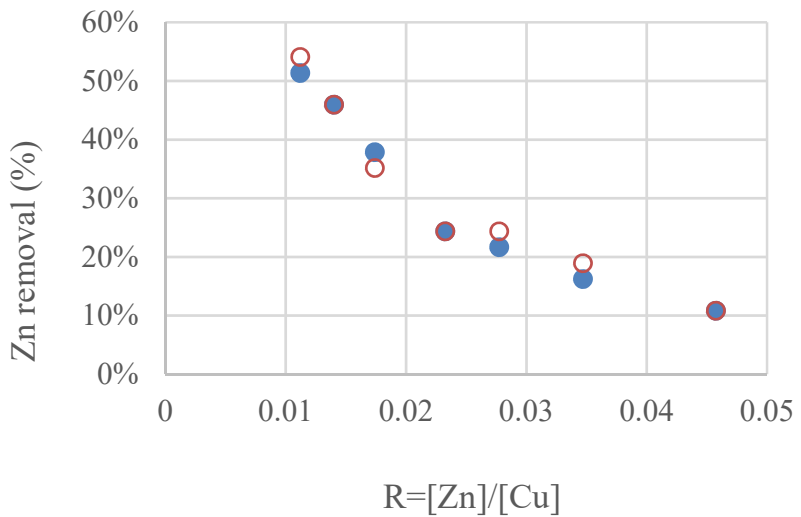

(c)

Figure 8: Removal of: (a) Al; (b) Ca; and (c) Zn from spiked catholytes with PCEAC (full circles) and PCEAMC (empty circles). 
Here as exposed in Fig. 8, it is suggested that $\mathrm{Al}, \mathrm{Ca}$, and $\mathrm{Zn}$ are removed by co-adsorption onto PCBets- $\mathrm{Cu}$ complexes otherwise their adsorption would have been observed in the unspiked catholytes. In the case of PCEAC, some copper desorption occurs (-25\%) with the increase of spiking copper concentration from 77-319 mg/L. Considering our previous results [5] showing that no copper desorption takes place in the presence of $\mathrm{Ca}$ or $\mathrm{Zn}$ (whatever is the ratio between 0.5-10), it is suggested that some copper is desorbed in favour of $\mathrm{Al}$ adsorption. No such desorption was observed in the case of PCEAMC suggesting that the chemical structure of PCBets can lead to different properties. The co-adsorption phenomena appears in Fig. 8, where the increase of copper spiking (low ratio) increase Al, $\mathrm{Ca}$ and/or $\mathrm{Zn}$ removal from solution.

\section{CONCLUSION}

- Less than $30 \%$ of $\mathrm{Cu}$ was removed from sewage sludge ash by electrodialytic removal, where most of the $\mathrm{Cu}$ was found in the catholyte after the treatment. Several metals and nutrients are present in the catholytes and needs separation for further valorization.

- The removal of $\mathrm{Cu}$ or other metal ions from the catholytes by PCBets directly was negligible due to the water-solubility of the $\mathrm{Cu}$-complexes.

- The PCBets can remove up to $70 \% \mathrm{Cu}$ from spiked catholytes, however a significant co-adsorption of both $\mathrm{Al}$ (up to $70 \%$ ) and $\mathrm{Ca}$ (up to 75\%) was seen.

There is a potential for combining electrodialytic remediation with using the novel PCBets for valorisation of metals. The electrodialytic process needs to be optimized to generate catholytes with higher concentrations. This could be done by for instance adding a concentration compartment in the set-up before the cathode or by using less electrolyte volume. To avoid co-adsorption of metals work of optimizing PCBets for the catholytes should be included in future work.

\section{ACKNOWLEDGEMENTS}

The authors wish to thank the Programme Sciences-IFD of the French-Danish Research Collaboration Program for initiating the cooperation between the institutions involved. Alicia Mendez is thanked for carefully conducting the electrodialytic remediation experiments through Erasmus exchange and Ebba Schnell for the ICP-OES analysis.

\section{REFERENCES}

[1] Ottosen, L.M., Kristensen, I.V., Pedersen, A.J., Hansen, H.K., Villumsen, A. \& Ribeiro, A.B., Electrodialytical removal of heavy metals from different solid waste products. Separation Science and Technology, 38(6), pp. 1269-1289, 2003.

[2] Ottosen, L.M., Jensen, P.E. \& Kirkelund, G.M., Phosphorous recovery from sewage sludge ash suspended in water in a two-compartment electrodialytic cell. Waste Management, 51, pp. 142-148, 2016.

[3] Kappel, A., Viader, R.P., Kowalski, K.P., Kirkelund, G.M. \& Ottosen, L.M., Utilisation of electrodialytically treated sewage sludge ash in mortar. Waste and Biomass Valorization, in press. DOI: 10.1007/s12649-018-0215-z.

[4] Ahmaruzzaman, M., Industrial wastes as low-cost potential adsorbents for the treatment of wastewater laden with heavy metals. Advances in Colloid and Interface Science, 166(1), pp. 36-59, 2011.

[5] Mouton, J., Turmine, M., Van den Berghe, H. \& Coudane, J., A water-soluble polycarbobetaine for sustainable copper recovery. International Journal of Sustainable Development and Planning, 11(2), pp. 192-202, 2016. 
[6] Mouton, J., Turmine, M., Van den Berghe, H. \& Coudane, J., A new water-soluble polycarbobetaine showing high selectivity toward copper. Chemical Engineering Journal, 283, pp. 1168-1175, 2016.

[7] Ottosen, L.M., Kirkelund, G.M. \& Jensen, P.E., Extracting phosphorous from incinerated sewage sludge ash rich in iron or aluminium. Chemosphere, 91, pp. 963969, 2013.

[8] Chen, G., Electrochemical technologies in wastewater treatment. Separation and Purification Technology, 38, pp. 11-41, 2004.

[9] Kirkelund, G.M., Damoe, A.J. \& Ottosen, L.M., Electrodialytic removal of Cd from biomass combustion fly ash suspensions. Journal of Hazardous Materials, 250-251, pp. 212-219, 2013.

[10] Kirkelund, G.M., Jensen, P.E., Villumsen, A. \& Ottosen, L.M., Test of electrodialytic upgrading of MSWI APC residue in pilot scale: focus on reduced metal and salt leaching. Journal of Applied Electrochemistry, 40, pp. 1049-1060, 2010. 